Якимчук T. I. ${ }^{[1 ; 0 R C I D ~ I D: 0000-0003-2983-1329], ~}$

ст. викладач,

Красовська Ю. В. ${ }^{[1 ; 0 R C I D ~ I D: ~ 0000-0002-5786-3267], ~}$ к.е.н., доцент

Подлевська О. М. ${ }^{[1 ;}$ ORCID ID:0000-0003-4979-9282] к.е.н., доцент

${ }^{1}$ Національний університет водного господарства та природокористування, м. Рівне

\title{
МЕТОДИ УПРАВЛІННЯ МИТНИМИ РИЗИКАМИ В ЗОВНІШНЬОЕКОНОМІЧНІЙ ДІЯЛЬНОСТІ
}

Статтю присвячено аналізу перспектив використання стратегічних методів управління митними ризиками В зовнішньоекономічній діяльності підприємств.

Участь України В міжнародних організаціях, посилення зовнішньоекономічного співробітницта, забезпечення конкурентоспроможності на світовому ринку, підвищення рейтингу держави у світовій спільноті, впровадження міжнародних стандартів потребує реформування сучасної політичної, правової, економічної, фінансової, соціальної та інших систем нашої держави.

Ключові слова: зовнішньоекономічна діяльність; митні процедури; ризики; підприємство.

Вступ. Основною метою оцінювання і обґрунтування ризику в будь-якій галузі народного господарства $\epsilon$ забезпечення його мінімальної шкоди для господарської діяльності, тому в науковій i господарській практиці застосовують різноманітні прийоми, методи та заходи управління ризиком (ризик - менеджменту), мета i завдання якого - розробити комплекс заходів зі зниження шкоди для господарюючого суб'єкта в разі настання ризикованої події на основі отриманої інформації.

Аналіз останніх досліджень і публікацій. В економічній літературі існує значна кількість характеристик поняття «управління ризиком», які зводяться до визначення його як процесу впливу на керований об'єкт, метою якого $€$ пошук можливих шляхів зниження ризику або його оптимізації [1, С. 43]. Але таке визначення $€$ дещо звуженим, тому що не включає в себе діапазон охоплюваних ризиків. Тому управління ризиками будемо визначати як процес впливу на суб'єкт господарської діяльності, при якому забезпечується максимально широкий діапазон охоплення 
потенційних ризиків, їх обґрунтоване прийняття та зведення ступеня впливу ризиків до мінімально можливих меж, а також розробка стратегії поведінки даного суб'єкта в випадку настання конкретних ризикових подій.

3 визначення поняття управління ризиком та його природи випливає, що основною метою менеджменту ризику є оптимізація роботи об'єкта (зокрема в зовнішньоекономічній діяльності) за критерієм раціоналізації ризиків. При цьому раціоналізація ризику це не обов'язково його мінімізація, а обґрунтування такого його рівня, що забезпечував би не лише максимальну очікувану ймовірність досягнення мети діяльності в конкретних умовах, але i сприяв би зміцненню та росту ефективності діяльності підприємства через виконання своїх позитивних функцій.

Базовими міжнародними нормами визначають принципи i основні направлення діяльності митних органів в області управління ризиками $€$ стандартні правила, які зазначені у Міжнародній конвенції про спрощення і гармонізацію митних процедур (Конвенція Кіото).

На основі вищесказаного можна сформулювати такі завдання управління митним ризиком в зовнішньоекономічній діяльності підприємств:

1. Формування комплексу ризиків на основі визначення всіх можливих сприятливих і негативних наслідків в процесі зовнішньоекономічної діяльності.

2. Якісний та кількісний аналіз всіх складових комплексу ризику.

3. Вибір та обґрунтування методів ризик - менеджменту на основі принципів його раціоналізації.

4. Прийняття рішень щодо діяльності підприємства на основі критерію раціонального ризику з урахуванням стратегії його оптимізації.

При виборі стратегії управління ризиком, згідно з теорією ризик-менеджменту, в конкретній ситуації спираються на чотири основні принципи, яких необхідно дотримуватись [2, С. 291]:

- стратегії передачі ризику третій стороні (страхуйте) в тих ситуаціях, коли можливі збитки внаслідок несприятливих подій значимі, а ймовірність їх настання невелика;

- стратегії уникнення ризику в ситуаціях, коли збитки внаслідок несприятливих подій значимі, а ймовірність їх настання велика;

- стратегії контролю ризику в тих ситуаціях, коли величина збитків внаслідок настання несприятливих подій незначна, а ймовірність настання висока; 
- стратегії прийняття ризику в тих випадках, коли збитки внаслідок настання несприятливих подій незначні і невеликою $€$ ймовірність їх настання.

Спираючись на зазначене, в зовнішньоекономічній діяльності підприємств та організацій можна виділити такі стратегічні напрямки оптимізації ризиків:

- мінімізація ризиків;

- запобігання ризиків;

- врахування та компенсація ризиків.

За результатами досліджень, проведених вітчизняними та зарубіжними науковцями в сфері управління ризиками [2-7] необхідно визначити основні перспективи використання кожного 3 цих стратегічних напрямків (табл. 1), враховуючи що кожен з них має ряд недоліків. Це дозволить встановити систему стратегічних методів для управління ризиками зовнішньоекономічної діяльності, що сприятиме підвищенню їі ефективності та підвищенню рівня конкурентоспроможності українських підприємств на світових ринках.

Основними недоліками методів мінімізації $€$ те, що вони поперше, вимагають значних додаткових затрат для проведення заходів контролю, прогнозування та моніторингу, по-друге, залишають ймовірність понести збитки і, відповідно, по-третє, не підходять для більшості критичних, а тим більше катастрофічних ризиків.

При широкому підході до формування та застосування комплексу превентивних заходів можна отримати значне зниження ймовірності ризику. Однак висока вартість превентивних заходів значно збільшує не лише собівартість продукції, яка є результатом господарської діяльності, але і величину збитків у випадках, якщо ризикова подія все ж таки станеться, адже ймовірність ії настання хоча і зменшується, проте не зводиться до нуля. Тому при застосуванні превентивних заходів слід проводити оцінку очікуваних результатів від них та затрат на їх здійснення.

При компенсації ризиків за рахунок власних коштів підприємства забезпечується безперебійність діяльності навіть у випадку настання ризикової події. Проте, оскільки основними методами даного шляху є формування резервно-страхових фондів та підтримка мобільності ліквідних активів в достатній сумі, це вимагає або замороження частини обігових коштів, що неефективно, або проведення постійної ефективної фінансової політики (а остання сама по собі $€$ сферою з досить високим рівнем ризику). Все 
вищезазначене значно обмежує застосування методів такої стратегії управління ризиком, проте для окремих видів ризику з невисоким розміром збитків і значною загрозою для безперервності діяльності підприємства застосування цього напрямку є правомірним.

Страхування як метод компенсації ризиків є більш ефективним шляхом ніж створення власних страхових резервів, оскільки не вимагає вилучення з обороту підприємства значної суми коштів. Проте і страхування має ряд недоліків: по-перше, не всі види ризику можна застрахувати в страхових компаніях; по-друге, оцінені страховою компанією збитки в разі настання ризикової події не завжди співпадають з фактичними збитками підприємства (через відмінність методологічного підходу до оцінки таких збитків); потретє, в страхуванні обов'язково має місце франшиза, а це значить, що частина збитків залишиться непокритою; по-четверте, між настанням ризикової події та моментом відшкодування збитків страховою компанією існує об'єктивно обумовлений проміжок часу, який може стати для підприємства часом простою і джерелом інших нових збитків. Враховуючи вищезазначене слід додати, що страхування може бути ефективним компенсаційним заходом, але лише для деяких конкретних ризиків, за умови, якщо ризикова подія методологічно чітко визначена між двома сторонами (страховиком та страхувальником), встановлено розміри збитків, що відшкодовуватимуться останнім і це влаштовує обидві сторони. Велике значення також відіграє попередній підбір критеріїв вибору страхової компанії та оцінка ефективності страхування шляхом співставлення величини потенційних втрат з сумарною величиною страхових платежів.

Безперечно, кожен з визначених шляхів та методів, як і кожна стратегія, мають свої позитивні та негативні якості.

Тому найкращим і найбільш ефективним буде таке управління зовнішньоекономічними ризиками в діяльності підприємств, яке забезпечить комплексне їх використання і застосування на різних етапах і в різних сферах прийняття та обґрунтування господарських рішень. 
Таблиця 1

Характеристика стратегічних напрямків оптимізації ризиків зовнішньоекономічної діяльності підприємств

\begin{tabular}{|c|c|c|c|c|}
\hline Напрям & Суть напрямку & Сфера використання & Шляхи & Методи \\
\hline 1 & 2 & 3 & 4 & 5 \\
\hline \multirow[t]{3}{*}{$\begin{array}{l}\text { Мінімі- } \\
\text { зація }\end{array}$} & \multirow[t]{3}{*}{$\begin{array}{l}\text { Керівник, що приймає } \\
\text { ризиковане рішення, } \\
\text { згідний взяти на себе } \\
\text { певний ризик }\end{array}$} & \multirow{3}{*}{$\begin{array}{l}\text { Обирається, коли ймовірність } \\
\text { настання ризикової події } \\
\text { коливається від низької до } \\
\text { високої, а збитки від її настання } \\
\text { характеризуються як незначні; } \\
\text { потенційні ризики відносяться до } \\
\text { зони допустимих і, частково, до } \\
\text { зони критичних ризиків; } \\
\text { суб'єктивна схильність до ризику }\end{array}$} & $\begin{array}{l}\text { Управління ризиками, що } \\
\text { необхідно приймати } \\
\text { (вбудовані в структуру } \\
\text { господарської діяльності) }\end{array}$ & $\begin{array}{l}\text { Постійний збір та обробка інформації про зміни станів } \\
\text { системи з тим, щоб запобігти необґрунтованому зростанню } \\
\text { рівня ризику }\end{array}$ \\
\hline & & & $\begin{array}{l}\text { Управління ризиками, які } \\
\text { можна собі дозволити (із зони } \\
\text { допустимих ризиків) }\end{array}$ & $\begin{array}{l}\text { Методи мінімізації ризику на основі побудови оптимізаційних } \\
\text { моделей ризикованого рішення; } \\
\text { методи мінімізації на основі прогнозування зміни рівня } \\
\text { ризику; } \\
\text { методи дисипації та диверсифікації (наприклад, розподілу } \\
\text { ризику в часі та диверсифікація видів діяльності та зон } \\
\text { господарювання тощо); } \\
\text { активний моніторинг середовища ризику }\end{array}$ \\
\hline & & & $\begin{array}{l}\text { Управління ризиками, які не } \\
\text { можна не дозволити } \\
\text { (можливість «прориву») }\end{array}$ & $\begin{array}{l}\text { Методи локалізації ризику, мета яких - усунути небезпеку для } \\
\text { функціонування підприємства в цілому від ризику даного } \\
\text { конкретного проєкту }\end{array}$ \\
\hline \multirow[t]{2}{*}{$\begin{array}{l}\text { Запобі- } \\
\text { гання }\end{array}$} & \multirow[t]{2}{*}{$\begin{array}{l}\text { В процесі аналізу ризику } \\
\text { приймається рішення } \\
\text { щодо зведення до нуля } \\
\text { або значного зниження } \\
\text { ступеня ймовірності } \\
\text { настання ризикової події }\end{array}$} & \multirow{2}{*}{$\begin{array}{l}\text { Наявність потенційних значних } \\
\text { збитків з одночасною високою } \\
\text { ймовірністю настання або при } \\
\text { попаданні розрахункового ризику в } \\
\text { зону катастрофічних ризиків; при } \\
\text { обгрунтуванні рішення з меншим } \\
\text { ступенем ризику для гарантування } \\
\text { надійності роботи системи в } \\
\text { сукупності з іншими напрямками їх } \\
\text { оптимізації; високий рівень } \\
\text { ризикованості галузі }\end{array}$} & 1) Уникнення ризику & $\begin{array}{l}\text { Відмова від здійснення видів діяльності, що можуть спричинити } \\
\text { настання прогнозованої ризикової події; } \\
\text { моделювання ризикової ситуації, виявлення факторів, що } \\
\text { спричиняють їі і усунення (в разі можливості) дії небезпечних } \\
\text { факторів або якомога більшого послаблення їх дії; } \\
\text { генерування нового альтернативного рішення зі значно меншим } \\
\text { рівнем ризику та інші подібні заходи }\end{array}$ \\
\hline & & & 2) Запобігання ризику & $\begin{array}{l}\text { Превентивні (попереджувальні) технічні, організаційні, соціальні } \\
\text { та інші заходи }\end{array}$ \\
\hline $\begin{array}{l}\text { Враху- } \\
\text { вання та } \\
\text { компен- } \\
\text { сація }\end{array}$ & $\begin{array}{l}\text { Ризик приймається, проте } \\
\text { паралельно суб'єкт } \\
\text { вишукує шляхи для } \\
\text { покритяя негативних нас- } \\
\text { лідків (збитків та втрат) } \\
\text { від ризикової події }\end{array}$ & $\begin{array}{l}\text { Наявність ризику, що } \\
\text { характеризується низьким ступенем } \\
\text { ймовірності та значними збитками } \\
\text { або ризик, що попадає в зону } \\
\text { критичного ризику }\end{array}$ & $\begin{array}{l}\text { 2) Формуванні джерел } \\
\text { компенсації за рахунок коштів } \\
\text { підприємства }\end{array}$ & $\begin{array}{l}\text { Пряме страхування, що регламентується Законом України «Про } \\
\text { страхування»; } \\
\text { непряме страхування шляхом обумовлення в контракті } \\
\text { відповідальності за настання ризикової події і такого } \\
\text { перерозподілу доходів, що компенсують згоду однієї зі сторін } \\
\text { брати на себе цю відповідальність, хеджування ризиків. } \\
\text { Формування резервно-страхових фондів }\end{array}$ \\
\hline
\end{tabular}


Таким чином, можна сформулювати основне завдання у виборі стратегії управління ризиком - створення комплексу, що включав би елементи різних методів та напрямків оптимізації ризиків в їх найкращому співвідношенні. Алгоритм обґрунтування стратегії управління ризиками наведено на рисунку.

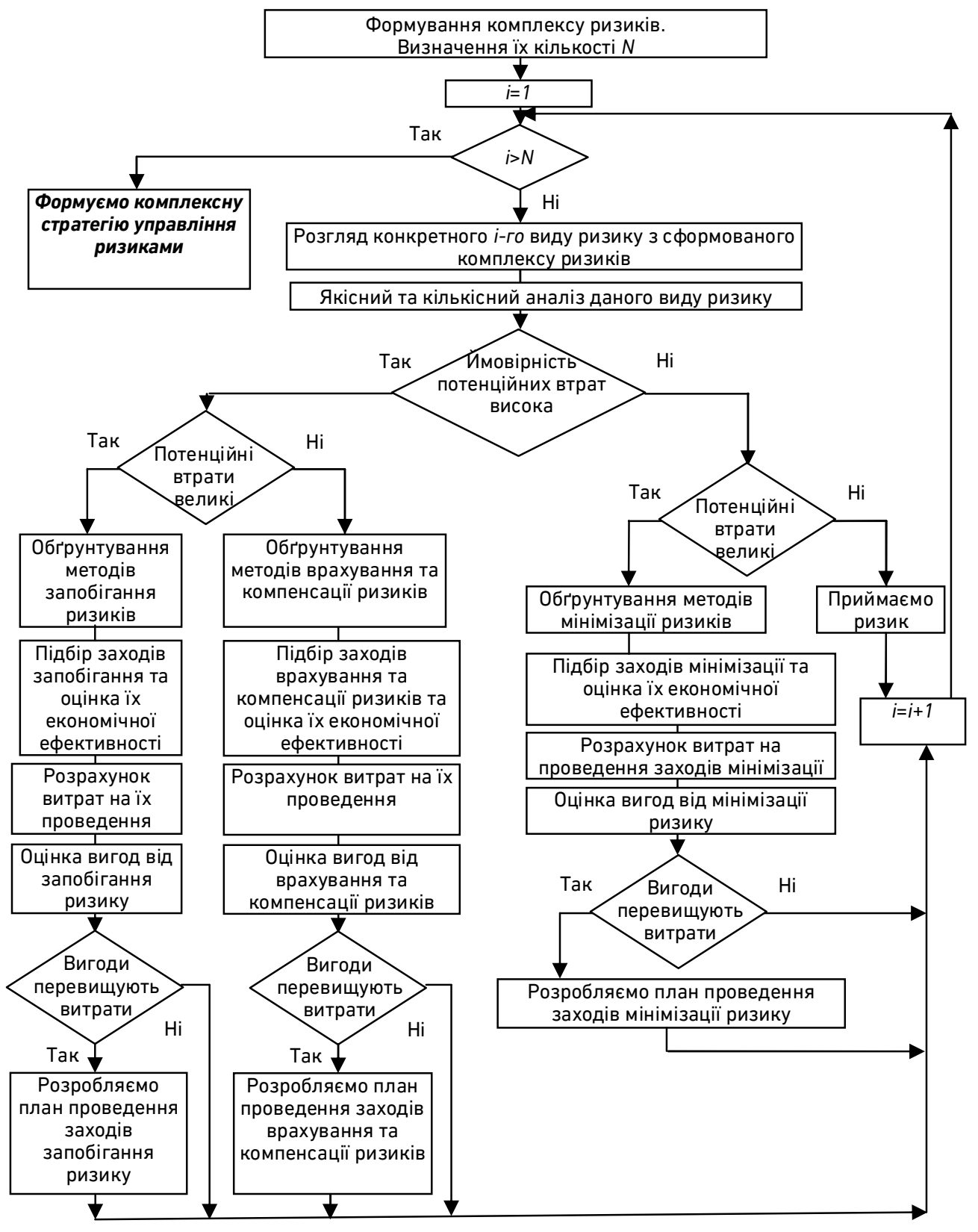

Рисунок. Алгоритм обґрунтування комплексної стратегії управління ризиками 
На базі проведених теоретичних досліджень пропонуємо використовувати наступну систему методів оптимізації ризику, які доцільно включити в стратегію управління ризиками в зовнішньоекономічній діяльності підприємств (табл. 2).

Таблиця 2

Характеристика методів управління ризиками зовнішньоекономічної діяльності підприємств

\begin{tabular}{|c|c|}
\hline Види ризику ЗЕД & Методи управління ризиками \\
\hline 1 & 2 \\
\hline \multicolumn{2}{|r|}{ Методи мінімізації ризику: } \\
\hline $\begin{array}{l}\text { Економіко-політичні } \\
\text { ризики країн }\end{array}$ & $\begin{array}{l}\text { Постійний контроль (моніторинг) за економіко- } \\
\text { політичною ситуацією в країні-партнері }\end{array}$ \\
\hline $\begin{array}{l}\text { Економіко-політичні } \\
\text { ризики країн }\end{array}$ & $\begin{array}{l}\text { Постійне прогнозування соціально-економічних } \\
\text { та політичних змін в країні-партнері }\end{array}$ \\
\hline $\begin{array}{l}\text { Економіко-політичні } \\
\text { ризики країн }\end{array}$ & Диверсифікація країн-партнерів \\
\hline $\begin{array}{l}\text { Економіко-політичні } \\
\text { ризики країн }\end{array}$ & $\begin{array}{l}\text { Постійний прогноз коливання обсягів } \\
\text { експортно-імпортних операцій в країнах } \\
\text { підприємств-партнерів }\end{array}$ \\
\hline Митний ризик & $\begin{array}{l}\text { Ретельний збір інформації про проходження } \\
\text { митних процедур }\end{array}$ \\
\hline $\begin{array}{l}\text { Ризики міжнародного } \\
\text { маркетингу }\end{array}$ & $\begin{array}{l}\text { Диверсифікація видів продукції, } \\
\text { зовнішньоекономічних операцій тощо }\end{array}$ \\
\hline Валютний ризик & Диверсифікація валют платежу \\
\hline $\begin{array}{l}\text { Ризик міжнародного } \\
\text { контракту }\end{array}$ & $\begin{array}{l}\text { Детальне опрацювання всіх пунктів контракту і } \\
\text { збір додаткової інформації }\end{array}$ \\
\hline $\begin{array}{l}\text { Ризики міжнародних } \\
\text { перевезень або } \\
\text { транспортні ризики }\end{array}$ & $\begin{array}{l}\text { Диверсифікація транспортних засобів та } \\
\text { способів доставки вантажу }\end{array}$ \\
\hline $\begin{array}{l}\text { Ризики, пов'язанні з } \\
\text { іноземним } \\
\text { контраґентом }\end{array}$ & $\begin{array}{l}\text { Диверсифікація партнерів, впровадження } \\
\text { цінової еластичності }\end{array}$ \\
\hline $\begin{array}{l}\text { Ризики міжнародного } \\
\text { конкурентного } \\
\text { середовища }\end{array}$ & $\begin{array}{l}\text { Отримання додаткової інформації про } \\
\text { функціонування на світовому ринку певного } \\
\text { товару великих конкуруючих корпорацій }\end{array}$ \\
\hline \multicolumn{2}{|r|}{ Методи запобігання ризику: } \\
\hline $\begin{array}{l}\text { Економіко-політичні } \\
\text { ризики країн }\end{array}$ & $\begin{array}{l}\text { Відмова від ризикованих партнерів, від } \\
\text { постачання в країни з підвищеним рівнем } \\
\text { політичного ризику }\end{array}$ \\
\hline $\begin{array}{l}\text { Ризики міжнародних } \\
\text { перевезень або } \\
\text { транспортні ризики }\end{array}$ & $\begin{array}{l}\text { Техніко-організаційні заходи підвищення } \\
\text { надійності перевезення товарів: перевірка } \\
\text { транспортних засобів, надійне пакування } \\
\text { товару, дотримання правил перевезень }\end{array}$ \\
\hline
\end{tabular}


продовження табл. 2

\begin{tabular}{|c|c|}
\hline \multicolumn{2}{|r|}{ Методи компенсації ризику: } \\
\hline $\begin{array}{l}\text { Валютний ризик, } \\
\text { ризики міжнародних } \\
\text { перевезень або } \\
\text { транспортний ризик, } \\
\text { ризики міжнародного } \\
\text { контракту }\end{array}$ & $\begin{array}{l}\text { Непряме страхування від через укладання } \\
\text { ф'ючерсних та форвардних угод }\end{array}$ \\
\hline $\begin{array}{l}\text { Валютний ризик, } \\
\text { ризики, пов'язанні } 3 \\
\text { іноземним }\end{array}$ & $\begin{array}{l}\text { Розрахунок ймовірних втрат від настання } \\
\text { ризикової події з визначенням резерву їх } \\
\text { покриття }\end{array}$ \\
\hline $\begin{array}{l}\text { контраґентом, } \\
\text { міжнародного }\end{array}$ & $\begin{array}{l}\text { Обґрунтування необхідності страхування в } \\
\text { страхових компаніях }\end{array}$ \\
\hline $\begin{array}{l}\text { маркетингу, } \\
\text { міжнародних } \\
\text { перевезень або } \\
\text { транспортні ризики, } \\
\text { міжнародного } \\
\text { конкурентного } \\
\text { середовища }\end{array}$ & $\begin{array}{l}\text { Встановлення на основі проєктних розрахунків } \\
\text { суми резервних коштів для покриття ймовірних } \\
\text { збитків з уточненням джерел покриття }\end{array}$ \\
\hline
\end{tabular}

Найбільш істотне місце в стратегії управління ризиками зовнішньоекономічної діяльності посідають методи мінімізації, специфіка яких проявляється в великому значенні контролю та інформаційному забезпеченню щодо можливих змін в середовищі ризику і забезпеченні гнучкості реагування на такі зміни з тим, щоб реалізувати процес господарювання 3 найменшими за даних конкретних умов втратами, а також різних форм диверсифікації - від країн-партнерів до валют платежу і видів продукції в експортноімпортних операціях.

Важливе місце в стратегії оптимізаційного управління ризиком посідають і методи компенсації, які представлені, в основному, створенням внутрішніх резервів коштів для покриття збитків, зверненням до страхових організацій, а також хеджуванням в міжнародних контрактах купівлі-продажу.

Формування стратегії управління ризиками в зовнішньоекономічній діяльності має здійснюватись на принципах ефективності цільового застосування [8, С. 83].

В митній діяльності за сферою виникнення ризики поділяються в залежності від місця або етапу митного контролю. Серед основних можна виділити наступні: можливі ризики, які мають місце в пунктах пропуску на державному кордоні та ризики, виникнення яких можливе під час транспортування товарів та транспортних засобів під митним контролем від одного митного органу до митного органу, який зазначений в документах контролю доставки.

В табл. 3 нами наведено основну нормативно-правову базу управління митними ризиками в Україні. 
Основні нормативно-правові документи, що регулюють питання управління митними ризиками в Україні

\begin{tabular}{|c|c|}
\hline Міжнародні & Вітчизняні \\
\hline $\begin{array}{l}\text { 1. Міжнародна конвенція про } \\
\text { спрощення та гармонізацію митних } \\
\text { процедур }\end{array}$ & $\begin{array}{l}\text { 1. Концепція створення, } \\
\text { упровадження і розвитку с системи } \\
\text { аналізу та керування ризиками та } \\
\text { Положення про систему й селекції } \\
\text { факторів ризику при визначенні } \\
\text { окремих форм митного контролю. }\end{array}$ \\
\hline $\begin{array}{l}\text { 2. Угода про спрощення процедур } \\
\text { торгівлі СОТ }\end{array}$ & $\begin{array}{l}\text { 2. Програма економічних реформ на } \\
\text { 2010-2014 роки «Заможне } \\
\text { суспільство, конкурентноспроможна } \\
\text { економіка, ефективна держава» }\end{array}$ \\
\hline $\begin{array}{l}\text { 3. Митний кодекс Союзу щодо } \\
\text { управління ризиками, прийнятий } \\
\text { відповідно до Регламенту (ЄС) } \\
\text { № } 952 / 2013 \text { Європейського } \\
\text { Парламенту та Ради від } 9 \text { жовтня } \\
2013 \text { року }\end{array}$ & $\begin{array}{l}\text { 3. Концепція реформування } \\
\text { діяльності митної служби України } \\
\text { «Обличчям до людей» }\end{array}$ \\
\hline $\begin{array}{l}\text { 4. Рамкові стандарти забезпечення } \\
\text { безпеки і спрощення процедур } \\
\text { міжнародної торгівлі Всесвітньої } \\
\text { митної організації }\end{array}$ & 4. Митний кодекс України \\
\hline \multirow[t]{2}{*}{$\begin{array}{l}\text { 5. Компендіум з управління } \\
\text { ризиками Всесвітньої митної } \\
\text { організації }\end{array}$} & $\begin{array}{l}\text { 5. Порядок здійснення аналізу та } \\
\text { оцінки ризиків, розроблення і } \\
\text { реалізації заходів з управління } \\
\text { ризиками в митній системі України }\end{array}$ \\
\hline & $\begin{array}{l}\text { 6. Стратегія розвитку системи } \\
\text { управління ризиками у сфері } \\
\text { митного контролю на період до } 2022 \\
\text { року }\end{array}$ \\
\hline
\end{tabular}

Реалізувати ідею управління ризиками, на нашу думку, можливо тільки втіливши програму «електронна митниця», тобто заздалегідь прийняти електронний варіант документів і до прибуття вантажу на митницю митна служба вже буде мати не тільки інформацію про вантаж, а головне вже буде прийнятий порядок дій інспектора по контролю та оформленню даного вантажу [9].

Таким чином можна зробити висновок про важливість наукової розробки понять та організації ефективної системи управління ризиками під час здійснення митних формальностей, що підтверджується міжнародним і національним законодавством. Розробка ефективної системи управління ризиками в митній діяльності дозволить зменшити ризики зовнішньоекономічної діяльності як з боку суб'єктів зовнішньоекономічної діяльності, так і $з$ 
1. Трегобчук В. М. Ринкова економіка, приватизація земель і екологія. Вісник аграрної науки. 1993. № 4. С. 3-10. 2. Андрійчук В., Бауер Л. Менеджмент: прийняття рішень і ризик : навч. посіб. К. : КНЕУ, 1998. 316 с. 3. Асамбаев Н. Оценка, анализ, измерение и управление рисками. Управление риском. 2002. № 1. С. 9-18. 4. Балабанов И.Т. Риск-менеджмент. М. : Финансы и статистика, 1996. 192 с. 5. Бузько И. Р., Трунина И.М., Загирняк Д.М. Экономический риск и управление инновационной деятельностью предприятия : учебное пособие. К. : ИСМО, 1996.136 с. 6. Вітлінський В. В., Наконечний С. І. Ризик у менеджменті. К. : ТОВ «Борисфен-М», 1996. 336 c. 7. Moore P. G. The bussiness of risk. Gambridge, 1983. 375 p. 8. Хвесик М.А., Ковшун Н.Е. До питання методології визначення екологоекономічної ефективності осушувальних меліорацій. Економіка України. 1996. № 4. С. 83-87. 9. Пісной П. Я. Митна політика та актуальні проблеми економічної та митної безпеки України на сучасному етапі. Ризики в зовнішньоекономічній діяльності : матеріали міжнародної науково-практичної конференції. Дніпропетровськ, 23 листопада 2007 р.

\section{REFERENCES:}

1. Trehobchuk V. M. Rynkova ekonomika, pryvatyzatsiia zemel i ekolohiia. Visnyk ahrarnoi nauky. 1993. № 4. S. 3-10. 2. Andriichuk V., Bauer L. Menedzhment: pryiniattia rishen i ryzyk : navch. posib. K. : KNEU, 1998. 316 s. 3. Asambaev N. Otsenka, analiz, izmerenie i upravlenie riskami. Upravlenie riskom. 2002. № 1. S. 9-18. 4. Balabanov I. T. Riskmenedjment. M. : Finansyi i statistika, 1996. 192 s. 5. Buzko I. R., Trunina I. M., Zagirnyak D. M. Ekonomicheskiy risk i upravlenie innovatsionnoy deyatelnostyu predpriyatiya : uchebnoe posobie. K. : ISMO, 1996. 136 s. 6. Vitlinskyi V. V., Nakonechnyi S. I. Ryzyk u menedzhmenti. K. : TOV «Borysfen-M», 1996. 336 s. 7. Moore P. G. The bussiness of risk. Gambridge, 1983. 375 p. 8. Khvesyk M. A., Kovshun N. E. Do pytannia metodolohii vyznachennia ekoloho-ekonomichnoi efektyvnosti osushuvalnykh melioratsii. Ekonomika Ukrainy. 1996. № 4. S. 83-87. 9. Pisnoi P. Ya. Mytna polityka ta aktualni problemy ekonomichnoi ta mytnoi bezpeky Ukrainy na suchasnomu etapi. Ryzyky $v$ zovnishnoekonomichnii diialnosti : materialy mizhnarodnoi naukovo-praktychnoi konferentsii. Dnipropetrovsk, 23 lystopada $2007 \mathrm{r}$.

Yakymchuk T. I. [1; ORCID ID: 0000-0003-2983-1329], Senior Lecturer,

Krasovska Y. V. [1: ORCID ID: 0000-0002-5786-3267], Candidate of Economics (Ph.D.), Associate Professor,

Podlevska O. M. [1; ORCID ID:0000-0003-4979-9282], Candidate of Economics (Ph.D.), Associate Professor

${ }^{1}$ National University of Water and Environmental Engineering, Rivne

\section{METHODS OF CUSTOMS RISK MANAGEMENT IN FOREIGN ECONOMIC ACTIVITY}

The article is devoted to the analysis of prospects for the use of strategic methods of customs risk management in the foreign economic activity of enterprises.

Ukraine's participation in international organizations, strengthening foreign economic cooperation, ensuring competitiveness in the world 
market, raising the country's rating in the world community, implementing international standards requires reforming the modern political, legal, economic, financial, social and other systems of our state. Foreign economic activity today is the most promising area of business. Considering that the pace of production in Ukraine has decreased, foreign economic activity is one of the most profitable activities.

As a rule, in the conditions of limited resource and financial opportunities each of the parties of business interests tries to find an opportunity to optimize the expenses and to increase the profit (profit) as much as possible. By adopting such rules of the game, businesses find themselves in a state of uncertainty and are on the verge of the legal field. Based on this, it is difficult to predict the course of events, but a desperate player in the market is trying to take risks in the hope of receiving a decent dividend (profit). This means that the risks have become the focus of attention of economists, lawyers and experts in various fields of knowledge.

International trade around the world is a major, accelerating force that affects the economic development of each country. The State Customs Service of Ukraine protects the economic interests of the state and monitors foreign economic activity, ie trade between countries. In this way, it optimizes the trading conditions of business entities.

Keywords: foreign economic activity; customs procedures; risks; enterprise.

\author{
Якимчук Т. И. [1; ORCID ID: 0000-0003-2983-1329], \\ ст. преподаватель, \\ Красовская Ю. В. [1: ORCID ID: 0000-0002-5786-3267] \\ К.э.Н., доцент,

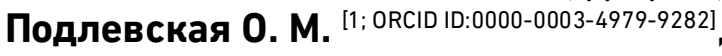 \\ к.э.н., доцент
}

${ }^{1}$ Национальный университет водного хозяйства и природопользования, г. Ровно

\title{
МЕТОДЫ УПРАВЛЕНИЯ ТАМОЖЕННЫМИ РИСКАМИ В ВНЕШНЕЭКОНОМИЧЕСКОЙ ДЕЯТЕЛЬНОСТИ
}

Цель исследования заключается в определении понятий, что такое риск, анализ риска, каким образом осуществляется управление рисками и определение критериев риска, как могут таможенные органы (таможенные администрации) минимизировать риски.

Внешнеэкономическая деятельность на сегодняшний день представляет собой наиболее перспективное направление бизнеса. Учитывая то, что темпы производства в Украине снизились, внешнеэкономическая деятельность является одной из рентабельных видов деятельности.

Ключевые слова: внешнеэкономическая деятельность; таможенные процедуры; риски; предприятие. 